\title{
A Tribute to George Cameron Coggins, Public Lands Maverick
}

\section{Robert L. Glicksman*}

Writing a conventional tribute to George Coggins is like trying to fit a square peg into a round hole. George was not big on convention. "Refreshingly irreverent" is the way one of his fellow public lands scholars described him. Another called him "one in a million, in a million different ways." As Professor Jim May recalled in the days following George's passing, the file cabinet in his office was adorned with a sticker urging those brave enough to enter his "sorcerer's den" to "subvert the dominant paradigm."

Nor was George much for personal accolades. He cared deeply about his family, the University of Kansas, its law school, his work, and the preservation of the natural resources to which he devoted his academic career. George cared less about what academics or others in the legal profession thought about him. That was unfortunate, because if he had paid more attention, he would have recognized, and perhaps even appreciated, the high regard with which his fellow public lands travelers held him. That George was a giant in his chosen field was clearly attested to in a string of emails submitted to a listserv of environmental law professors that commemorated and celebrated George and his pathbreaking scholarship. I'll have more to say about those tributes below in connection with assessment of the impact of George's scholarship.

\footnotetext{
* J.B. \& Maurice C. Shapiro Professor of Environmental Law, The George Washington University Law School. Professor Glicksman was a member of the faculty of the University of Kansas School of Law from 1982 to 2009 and served as the Robert W. Wagstaff Distinguished Professor of Law from 1995 to 2009.

1. Jim was one of George's students and research assistants at the University of Kansas School of Law. He became a successful environmental litigator and later a Distinguished Professor of Law and cofounder and codirector of the Dignity Rights Project and the Environmental Rights Institute at Widener University Delaware Law School. Jim earned a B.S. in Mechanical Engineering and his J.D. at KU and an LL.M. from Pace University School of Law. Faculty Directory: Jim May, WIDENER UNIV. DEL. LAW SCH., https://delawarelaw.widener.edu/current-students/faculty-directory/faculty $/ 122$ [https://perma.cc/MEZ5-5YYS] (last visited Mar. 26, 2020).
} 


\section{The Origins and Development of a Legal Maverick}

George was born in Pontiac General Hospital in Pontiac, Michigan on January 27, 1941. ${ }^{2}$ His parents, Charles George Coggins (who went by Chuck) and Evelyn Jean Coggins (who went by Jean) were both educators. ${ }^{3}$ Chuck, whom George described as a "renegade Catholic[]," successfully battled polio beginning when George was seven or eight years old. ${ }^{4}$ Nevertheless, he managed to serve as superintendent of a couple of public school systems. ${ }^{5}$ So the seeds of George's willingness to ignore convention may have been planted early on. Jean, a Canadian who became a naturalized U.S. citizen, taught English and Journalism. ${ }^{6}$ George thus came by his thirst for knowledge and the desire to share it with others honestly, though he insisted that he spent more time being a "screw-off[]" than studying throughout his days as a student. ${ }^{7}$

George's family (which included his younger brother, Dale, and his younger sister, Kathleen) lived in the small towns of Milford and Highland, Michigan before moving to Holly, a town between Pontiac and Flint. ${ }^{8}$ To George's delight, he got an A in the Journalism course taught by his mother, while Dale received only a B. ${ }^{9}$ One can only conclude that Jean recognized, and helped hone, George's writing skills early on. George lettered in four sports while at Holly High School, describing himself as "decent in two and really bad in two others." 10 One suspects he undersold his talents, and not for the last time. For one, the basketball team made the state finals in George's senior year. ${ }^{11}$ For another, George attended Central Michigan University on a football scholarship, where he also enjoyed playing pick-up basketball. ${ }^{12}$ After injuring his knee playing football during his sophomore year, George excelled at his course work despite being "a proto-typical irresponsible college student."13

In George's telling, he had decided to become a lawyer as early as

2. Interview with George Cameron Coggins, Frank E. Tyler Professor of Law, Univ. of Kan. Sch. of Law 3 (June 15, 2010), http://www.kuonlinedirectory.org/endacott/data/OralHistory Transcripts/george\%20coggins\%20final.pdf [https://perma.cc/UPG7-D8NW] [hereinafter Interview with Professor Coggins].

3. Id.

4. Id.

5. Id.

6. Id.

7. Id. at 5 .

8. Id. at 3 .

9. Id. at 4 .

10. Id. at 5 .

11. Id. at 4-5.

12. Id. at 6.

13. Id. 
eighth or ninth grade, even though his father's attitude towards lawyers lay somewhere between "dislike and contempt." 14 The combined promise of "no heavy lifting" and solid earning potential nevertheless lured George to apply to the prestigious University of Michigan Law School. ${ }^{15}$ "To the utter amazement of [his] classmates," George "was fairly good at it," performed "better than reasonably well," and earned the honor of serving on the Michigan Law Review. ${ }^{16}$

More importantly, during his third year in law school, George met his future wife Margaret Ann (Margie) in a bar, declaring later that he was immediately "smitten" and "made a fool of myself." 17 It must have worked, even though Margie's first impression was that George was likely a truck driver. ${ }^{18}$ They were married exactly two years later on January 27 , 1968 (which also happened to be George's birthday). ${ }^{19}$ Five years after that, their daughter, Andrea, arrived, followed by Rebecca and then Michael. $^{20}$ That tight-knit family unit spent the following decades enjoying each other's company in far flung corners of the world, taking advantage of the flexibility that the academic calendar afforded them. ${ }^{21}$ Margie became a Librarian and Media Specialist in the Lawrence public school system. ${ }^{22}$

After graduating, George worked as a litigation attorney for the San Francisco "blue stocking" law firm of McCutchen, Doyle, Brown \& Enersen. ${ }^{23}$ He specialized in Jones Act (marine insurance) and product liability cases, sometimes juggling as many as a couple of hundred cases at the same time. ${ }^{24}$ But George's small-town roots made a daily commute through city traffic unacceptable, so George and Margie began looking for a way to escape the San Francisco lifestyle. ${ }^{25}$

14. Id. at 6-7.

15. Id. at 7 .

16. Id. at 9 .

17. Id. at 10 .

18. Id.

19. Id. at 11 .

20. Id.

21. Id. at 12 .

22. Id. at 11 .

23. Id. at 9 .

24. Id.

25. Id. George's distaste for the "big city" never left him. After I left the KU Law faculty and moved to the Washington, D.C. area in 2009, I told George that he and Margie were welcome to visit and stay with me and my wife, Emily, any time and we'd show them the best of D.C. George made it abundantly clear that it would never happen. He had no interest in slogging through the traffic and breathing in the inferior air quality, even for a couple of days. As a result, if I wanted to keep up with George, I'd have to visit him in Lawrence, which I did, regularly. Email was out of the question, since George "didn't do" computers. Legend has it that when he finally accessed his computer shortly 


\section{George Coggins Meets KU Law (and Vice Versa)}

According to George, he was offered the opportunity to teach at the University of Kansas (KU) "almost by accident" after he attended a law school convention in San Francisco. ${ }^{26}$ He and Margie agreed to try living in Lawrence "as an experiment," intending to test out KU for a year to "see if it was copacetic." 27 It must have been, because the family spent nearly the next fifty years as Jayhawks.

George and Margie arrived in Lawrence in August of $1970 .^{28}$ Literally two days after their arrival, having spent a couple of nights camping at a KOA Campground north of town, they bought the house of a former Journalism professor on Ohio Street and moved in immediately. ${ }^{29}$ The family was greeted rudely (to put it mildly). One of George's first official acts as a KU faculty member was to decide, as a member of the University Judiciary Committee, to uphold the decision of the KU track coach to kick one of his athletes off the team. ${ }^{30}$ The day after the newspaper reported what had happened, a pipe bomb blew up the family's mailbox. ${ }^{31}$ Fortunately, no one was injured, and, just as fortunately for KU Law and the thousands of students who would take George's courses, George and Margie were not deterred.

At the beginning of his time at KU, George taught Civil Procedure, Trial Practice, and Administrative Law, three subjects which were a natural fit for someone who had been involved in a litigation practice. George referred to these as "nuts and bolts" courses. ${ }^{32}$ But, as he acknowledged, his "true interests lay elsewhere." 33 George had joined the Sierra Club in San Francisco in 1968 primarily to get himself included on the softball team put together by the founders of the Sierra Club Legal

before retiring, his KU Law email account had more than 15,000 emails awaiting him. I have a hunch that he never got around to checking them out.

26. Id.

27. $I d$.

28. Id. at 7 .

29. $I d$.

30. Id. at 8 .

31. Id. In George's telling, he and Margie arrived at a time when "all kinds of difficulties on the campus and in Lawrence" were culminating. Id. at 7. The Vietnam War was raging, and when President Richard Nixon ordered the invasion of Cambodia in the spring of 1970, protests erupted at colleges and universities around the country. At the college I attended, students burned President Nixon in effigy the night of the invasion. Philip W. Semas, A Week of Tragedy: Disorders Flare, 4 Students Die as U.S. Action in Cambodia Inflames Many Campuses, CHRON. Higher EdUC. (May 11, 1970), https://www.chronicle.com/article/A-Week-of-Tragedy-Disorders/6375. At KU, students burned the student union. Fire and Smoke, KU HISTORY (Apr. 20, 1970), https://kuhistory.ku.edu /articles/fire-and-smoke [https://perma.cc/85Q4-86JA].

32. Interview with Professor Coggins, supra note 2 , at 13.

33. Id. 
Defense Fund. ${ }^{34}$ When he and Margie moved to Lawrence, George started a chapter of the Sierra Club in Lawrence and became chairman of both the local and state chapters. ${ }^{35}$ That experience, together with his interest in nature, resulted in a gradual shift in George's teaching and scholarly focus to environmental and natural resources law. ${ }^{36}$

Fortuitously, George joined the KU faculty just as modern U.S. environmental law was born. The National Environmental Policy Act, which requires agencies to evaluate the possible effects of their actions on the environment, ${ }^{37}$ went into effect in 1970 and later that year, Congress passed the Clean Air Act Amendments of $1970 .^{38}$ Congress continued to adopt environmental legislation throughout the 1970s, including, critically, organic statutes for two of the four principal agencies charged with managing the federal government's land and resource holdings, the U.S. Forest Service and the Bureau of Land Management (BLM). ${ }^{39}$

George's other inducement to switch academic specialties was an effort during the early 1970s to create a Tallgrass Prairie National Park in Kansas to include this unrepresented biome in the National Park System. ${ }^{40}$ The idea of creating a national park among the prairie ecosystem in Kansas dates back at least to 1832, but support for the idea grew as more and more of the undisturbed prairie was plowed under. ${ }^{41}$ The National Park Service (NPS) pushed for the park's creation because it wanted all biomes located in the United States represented in its holdings. George was fully on board, but ranching interests in central Kansas were not, and the effort stalled. ${ }^{42}$ A bill introduced in Congress in 1991 would have created a tallgrass prairie park from the 10,894-acre Spring Hill/Z Bar Ranch in the

\footnotetext{
34. Id.

35. Id.

36. Id.

37. 42 U.S.C. $\S 4332(2)(C)$ (2012 \& Supp. 2019).

38. Pub. L. No. 91-604, 84 Stat. 1676 (1970) (codified as amended at 42 U.S.C. $\S \S 7401-7671 q$ ).

39. National Forest Management Act (NFMA), Pub. L. No. 94-588, 90 Stat. 2949 (1976) (codified as amended at 16 U.S.C. $\S \S 1600-1687$ ) (the Forest Service's organic statute); Federal Land Policy and Management Act (FLPMA), Pub. L. No. 94-579, 90 Stat. 2744 (1976) (codified as amended at 43 U.S.C. $\S \S 1701-787$ ) (the BLM's organic statute). The other two principal land management agencies are the National Park Service (NPS) and the U.S. Fish and Wildlife Service (FWS). The NPS, whose organic statute was adopted in 1916, administers the national parks and other units of the National Park System. Act of Aug. 25, 1916, ch. 408, 39 Stat. 535 (codified as amended at 54 U.S.C. $\S \S 100101-104909)$. Congress adopted the organic statute for the FWS, which manages the national wildlife refuges, in 1966. National Wildlife Refuge System Administration Act of 1966, Pub. L. No. 89-669, 80 Stat. 927 (1966) (codified as amended at 16 U.S.C. $\S \S 668 \mathrm{dd}-668 \mathrm{ee}$ ).

40. Interview with Professor Coggins, supra note 2, at 13.

41. We Ought to Have Saved a Park in Kansas, NAT'L PARK SERV., https://www.nps.gov/tapr /learn/historyculture/we-ought-to-have-saved-a-park-in-kansas.htm [https://perma.cc/Q56P-X6M6] (last updated Jan. 5, 2017).

42. Interview with Professor Coggins, supra note 2, at 13.
} 
Flint Hills, but opposition to federal ownership of large landholdings helped sink that bill. ${ }^{43}$

Over the next several years, however, Kansas Senators Nancy Kassebaum and Bob Dole spearheaded a drive to create a national preserve, 180 acres of which would be owned by the federal government. ${ }^{44}$ The rest of the preserve would remain in the hands of the National Park Trust, which had purchased the Spring Hill/Z Bar Ranch in $1994 .{ }^{45}$ The upshot was the creation of the Tallgrass Prairie National Preserve as the 370th national park unit. ${ }^{46}$ The NPS's web page for the Preserve explains that "Today, the NPS and The Nature Conservancy work toward preservation of the tallgrass prairie, while sharing the story of ranching legacy, American Indian history, and the diverse tallgrass prairie ecosystem here in the heart of the scenic Flint Hills of Kansas." ${ }^{, 47}$

The controversy over the tallgrass prairie further stoked George's budding interest in federal land ownership and its myriad classifications. ${ }^{48}$ At the time, federal landholdings encompassed about a third of the surface acreage of the United States. ${ }^{49}$ That fact was highlighted in a report submitted to Congress - again in 1970 - by the Public Land Law Review Commission (PLLRC), titled One Third of the Nation's Land. ${ }^{50}$ Congress had established the PLLRC in 1964 as an independent agency to make recommendations for future management of the federal lands. ${ }^{51}$ The PLLRC's charge included studying existing statutes and regulations governing the retention, management, and disposition of the public lands; reviewing the policies and practices of the federal land management agencies; and recommending modifications in existing laws, regulations, policies, and practices to promote retention, management, and disposal of the federal public lands "in a manner to provide the maximum benefit for the general public." 52

\footnotetext{
43. We Ought to Have Saved a Park in Kansas, supra note 41.

44. Id.

45. $I d$.

46. Id.; Omnibus Parks and Public Lands Management Act of 1996, Pub. L. No. 104-333, $\S \S$ 1001-1009, 110 Stat. 4093, 4204-09 (codified in scattered sections of 16 U.S.C.).

47. We Ought to Have Saved a Park in Kansas, supra note 41.

48. Interview with Professor Coggins, supra note 2, at 13.

49. Id.

50. Pub. Land Law Review Comm'n, One Third of the Nation's Land (1970), https:// archive.org/details/onethirdofnation3431 unit/page/n1/mode/2up [https://perma.cc/93K2-463R].

51. Pub. L. No. 88-606, 78 Stat. 982 (1964) (“An Act for the establishment of a Public Land Law Review Commission to study existing laws and procedures relating to the administration of the public lands of the United States, and for other purposes.").

52. Pub. L. No. 88-606, §§ 1, 4(a), 78 Stat. 982, 982-83. For a review of the PLLRC's work and impact, see Robert B. Keiter \& Matthew McKinney, Public Land and Resources Law in the American West: Time for Another Comprehensive Review?, 49 ENVTL. L. 1, 35-46 (2019).
} 
The Trailblazing Casebook That Redefined Public Land Law

All of this activity must have seemed to George like an open invitation to contribute to the debate over the current status and future directions of federal land and resource management. And George did not shrink from the task. The exploration of natural resources law as part of the law school curriculum had begun in the 1950s, but the first textbooks on the subject "viewed natural resources law from a decidedly private property, allocative perspective." ${ }^{53}$ George thought there was more-a lot moreto be said about natural resources law. Serving as a trustee of the Rocky Mountain Mineral Law Foundation, he helped organize a seminar in 1979 for natural resources law teachers. ${ }^{54}$ There, he met Charles Wilkinson, ${ }^{55}$ who was then teaching at the University of Oregon. ${ }^{56}$ They decided to join forces and write a new law school casebook on public natural resources law. As George later described it, "This was a brand new thing. Nobody had ever heard of it." ${ }^{, 57}$ Professor Rob Fischman, ${ }^{58}$ who later joined the casebook along with John Leshy, ${ }^{59}$ identified as "the genius" of the Coggins-Wilkinson casebook:

[Its] embrace [of] the environmental disputes on the cutting edge of natural resources law [by] carv[ing] out a separate field of study revolving around publicly owned resources. This provided a comfortable margin of difference between the material in environmental law, which focused on the public regulation of private property, and the

53. Robert L. Fischman, What Is Natural Resources Law?, 78 U. COLO. L. REV. 717, 720 (2007).

54. Interview with Professor Coggins, supra note 2, at 14.

55. Charles Wilkinson is the Moses Lasky Professor of Law Emeritus at the University of Colorado Law School. He served as special counsel to the Interior Department during the Clinton Administration. See Charles Wilkinson, COLO. LAw, https://lawweb.colorado.edu/profiles /profile.jsp?id=65 (last visited Apr. 14, 2020).

56. Interview with Professor Coggins, supra note 2, at 14.

57. Id. In an article published contemporaneously with publication of the casebook, George described the rationale behind the organization and content of the new casebook:

It must be admitted that the volume will be experimental. In one sense it is unique- the conception, organization, and materials are without direct precedent. In another sense, however, the book is merely one more in a long line of attempts to adapt legal curricula to changing conditions and perceptions by rearranging old stuff in new forms and packages.

George Cameron Coggins, Some Disjointed Observations on Federal Public Land and Resources Law, 11 ENVTL. L. 471, 482 (1981).

58. Professor Fischman is the George P. Smith, II Distinguished Professor of Law at the Indiana University Maurer School of Law in Bloomington, Indiana. See Faculty: Robert L. Fischman, MAURER SCH. OF LAW, https://www.law.indiana.edu/about/people/bio.php?name=fischman-robert-l [https://perma.cc/A3RN-JEES] (last visited Mar. 26, 2020).

59. Professor Leshy is Emeritus Harry D. Sunderland and Distinguished Professor of Real Property Law at the UC Hastings College of Law. He served as Solicitor of the Department of the Interior during both terms of Bill Clinton's presidency. See People: John Leshy, UC HASTINGS Coll. OF LAW, https://www.uchastings.edu/people/john-leshy/ [https://perma.cc/NHW3-GEA6] (last visited Mar. 26, 2020). 
public natural resources class, which focused on public management and private claims on federal (and, to a lesser degree, state and tribal) property. ${ }^{60}$

In George's telling, he and Professor Wilkinson "added a bunch of layers" to the older books' focus on mineral development and water law, "including history, constitutional provisions, wildlife, range, timber, recreation, and preservation. And we treated them all as coequal resources, and that approach has become the standard since." 61 George also described the casebook's approach as "forcing some order on random sprawl." ${ }^{62}$ Others similarly regarded the book as paradigm-shattering. ${ }^{63}$ Professor Michael Blumm, a leading and prolific public lands scholar, put it this way:

More than any of the earlier texts, this casebook presented the rich cultural history of the law of natural resources, identifying landmark cases of the nineteenth and early twentieth century and establishing a Western canon of public lands and resource law.... Going beyond the earlier texts, this... casebook systematically elevated resource preservation to equal prominence with resource extraction and devoted significant space to the growing importance of recreation as a predominant use of public lands. ${ }^{64}$

Blumm also stated that the book "redefin[ed] natural resources law pedagogy." ${ }^{, 65}$

60. Fischman, supra note 53, at 721; see also John H. Davidson, The New Public Lands: Competing Models for Protecting Public Conservation Values on Privately Owned Lands, 39 ENVTL. L. REP. NEWS \& ANALYSIS 10368, 10369 (2009) (referring to the casebook as "precedent-setting"); Robert L. Glicksman, Pollution on the Federal Lands I: Air Pollution Law, 12 UCLA J. ENVTL. L. \& POL'Y 1, 60 (1993) (referring to the Coggins and Wilkinson casebook as "[t]he book that defined public natural resources law"); Keiter \& McKinney, supra note 52, at 44 (characterizing the book as "seminal").

61. Mindie Paget, Faculty Farewell, in KU LAw Mag., Fall 2010, at 12, 13, https://issuu.com /kulaw/docs/ku_law_magazine_f10 [https://perma.cc/7WBW-3UQX]; see also Michael C. Blumm \& David H. Becker, From Martz to the Twenty-First Century: A Half-Century of Natural Resources Law Casebooks and Pedagogy, 78 U. COLO. L. REV. 647, 674 (2007) (stating that the book "established the modern Western canon of public land and natural resource law").

62. Blumm \& Becker, supra note 61 , at 651.

63. George thus lived up to the bumper sticker in his office.

64. Blumm \& Becker, supra note 61, at 651. Professor Blumm is the Jeffrey Bain Faculty Scholar and Professor of Law at the Lewis \& Clark Law School. See Law Faculty: Michael Blumm, LEwIS \& CLARKE LAW SCH., https://law.lclark.edu/live/profiles/250-michael-blumm [https://perma.cc/SZM4 -4FGZ] (last visited Mar. 26, 2020).

65. Blumm \& Becker, supra note 61 , at 674-75. According to Professor Blumm, it did so by (1) following by a resource-by-resource discussion of applicable law and policy; (2) "us[ing] federal ownership of land and resources as a unifying concept, permitting examination of the allocation of private rights in public resources as well as how public values increasingly demanded the preservation and non-extractive use of public resources"; and (3) "effectively redefin[ing] the term "natural 
The first edition of the casebook was published by Foundation Press in 1981. ${ }^{66}$ According to George, notwithstanding (or perhaps because of) its novelty, the book "was, frankly, an instant success." Professor Blumm, writing in 2007, the Coggins and Wilkinson (and eventually Leshy and Fischman) casebook "dominated the field of natural resource law textbooks for the past twenty-five years." ${ }^{68}$ A number of competing books appeared subsequently ${ }^{69}$ but George's book, now in its seventh edition, ${ }^{70}$ is still a leader in its field.

\section{Other Public Lands Books}

George knew a good thing when he saw it. He decided to incorporate his transformative conception of federal public land law into two other books, one for legal practitioners and one for students. The first was a multi-volume treatise (the only one of its kind), Public Natural Resources Law, first published in 1990 by Clark Boardman. ${ }^{71}$ Although I was not a contributor to the Coggins-Wilkinson casebook, and my teaching at KU had focused on the pollution control side of environmental law, ${ }^{72}$ George

resource' by considering both traditional and emerging resources - such as recreation and preservation - on an equal footing." Id. at 675. Professor Blumm added these thoughts:

$[\mathrm{T}]$ he Coggins book went beyond its predecessors in two significant areas: first, it provided a far richer and more stimulating historical introduction to how public natural resources law developed; second, it raised non-extractive resources to a position of equality with extractive resources. Its focus on public land resources led to its near-exclusive attention on Western natural resources, with little or no consideration of private lands unrelated to federal lands. Nevertheless, this casebook established the modern Western natural resources law canon and has been the standard text for natural resources law for the past quarter-century.

Id. at 690 .

66. George Cameron Coggins \& Charles F. Wilkinson, Federal Public Land and RESOURCES LAW (1st ed. 1981).

67. Interview with Professor Coggins, supra note 2, at 14.

68. Blumm \& Becker, supra note 61 , at 651.

69. Professor Fischman has described the differences among some of them. See Fischman, supra note 53 , at $728-30$.

70. George Cameron Coggins, Charles F. Wilkinson, John D. Leshy \& Robert L. Fischman, FEDERAL PUbliC LAND AND RESOURCES LAW (7th ed. 2014).

71. George C. Coggins \& Robert L. Glicksman, Public Natural Resources LaW ( 1 st ed. 1990).

72. George's interest in the pollution control side of environmental law was transitory. When I applied for a faculty position at KU Law in the fall of 1981, I knew that the impression I made on George was a make-it-or-break-it deal. I guess he couldn't have objected too strongly because I got the job. At the interview, he told me that if KU hired me, I would have to teach the Clean Air Act because he never wanted to touch that statute again. George had taught that and the other pollution control statutes briefly after Tom McGarity, who taught at KU Law from 1977 to 1980, joined the University of Texas School of Law. After I joined the faculty, George never did teach pollution control law again. And I never got to teach natural resources law until I moved to GW Law. At KU, that was 
asked me to join him as co-author of the incipient treatise, which he had fully outlined but not yet begun writing. I eagerly accepted, delighted to be able to work with him on such a substantial project. ${ }^{73}$ We wrote a second edition of the treatise, expanding it from three volumes to four, which was published in 2007 and which continues to be updated three times each year. ${ }^{74}$ The second new book was a nutshell, first published in $1995^{75}$ and now in its fifth edition. ${ }^{76}$ Both books followed the organization of the Coggins and Wilkinson casebook.

\section{George Coggins in the U.S. Supreme Court}

In recognition of his national and international scholarly reputation, the University of Kansas named him the Frank Edwards Tyler Distinguished Professor of Law in 1983. The reception afforded his public lands casebook published two years earlier surely had much to do with this accolade. But George had made his mark in law review publications long before the casebook appeared. One of George's early works was one of the first law review articles that addressed the Endangered Species Act

George's exclusive domain.

I think I cemented George's positive impression (or at least tolerance) of me shortly after arriving at KU in 1982. George and Margie invited me to dinner at their house on Ohio Street. While we ate, George played a mixed tape he had put together of his favorite rock and roll songs. When one of the songs began playing, I identified it as "Easier Said Than Done" by The Essex, which had very briefly been a number one song on the Billboard charts nineteen years before in the summer of 1963 . See Easier Said Than Done, WIKIPEDIA, https://en.wikipedia.org/wiki/Easier_Said_Than_Done [https://perma.cc/22BD-A9ZP] (last visited Mar. 26, 2020). George stared at me with incredulity, I assume because I had recognized such an obscure song. I guess he figured I was alright at that point. George and I continued to discuss (argue about?) music over the years. George's favorite music was recorded in the 1950s. I was a child of the 1960s. He told me more than once that the Beatles had ruined rock and roll when they began to "take themselves seriously." One time, when I visited George while he was teaching a summer course in Anchorage, Alaska, we were driving to Denali National Park when the Beatles "Get Back" came on the car radio. When the song finished, I asked George what he thought of it. "Very good song," he responded. I told him it was recorded near the tail end of the Beatles' career as a group. Duly chastened, he admitted that the Beatles still had some good music left in them even after they became serious.

73. When I joined the KU faculty, George offered to co-author my first law review article. That collaboration, which clocked in at 112 pages, schooled me in the intricacies of the law review publication process. See Robert L. Glicksman \& George Cameron Coggins, Federal Recreational Land Policy: The Rise and Decline of the Land and Water Conservation Fund, 9 COLUM. J. ENVTL. L. 125 (1984). During the 1980s and 1990s, the two of us wrote several more articles dealing with groundwater pollution control, concessions law in the National Park System, wilderness management policy, mineral development on the federal lands, and recurring constitutional, procedural, and substantive issues concerning federal land and resources law.

74. George Cameron Coggins \& Robert L. Glicksman, Public Natural Resources LaW (2d ed. 2007). The treatise is a Thomson Reuters publication. One source describes the treatise as "the bible for public land and resource attorneys." Paget, supra note 61, at 13.

75. Robert L. Glicksman \& George Cameron Coggins, Modern Public Land Law (1995).

76. Robert L. Glicksman, Modern Public LAND Law (5th ed. 2019). 
(ESA), which Congress enacted in $1973 .^{77}$ George set out in that article to "explain in broad outline the aims of the new statute and the means chosen by Congress to accomplish those aims." ${ }^{\text {"78 }}$ The new statute instantly generated litigation, and by 1978, a dispute concerning the scope and effect of a key provision of the Act landed in the Supreme Court. The case, Tennessee Valley Authority v. Hill, ${ }^{79}$ addressed the application of the Act's "no jeopardy provision" 80 to a nearly completed dam being constructed by the Tennessee Valley Authority (TVA).

In a landmark decision, the Court ruled that the ESA applied to the Tellico Dam, that further construction of the dam would violate the no jeopardy provision by wiping out an endangered species of fish called the snail darter, and that the district court properly ordered the TVA to halt construction of the dam even though it was nearly complete. ${ }^{81}$ In doing so, the Court, in an opinion by Chief Justice Warren Burger, quoted a key portion of George's article to establish that Congress meant what it said in mandating compliance with the no jeopardy provision:

The dominant theme pervading all Congressional discussion of the proposed [Endangered Species Act of 1973] was the overriding need to devote whatever effort and resources were necessary to avoid further diminution of national and worldwide wildlife resources. Much of the testimony at the hearings and much debate was devoted to the biological problem of extinction. Senators and Congressmen uniformly deplored the irreplaceable loss to aesthetics, science, ecology, and the national heritage should more species disappear. ${ }^{82}$

For any legal academic whose work is cited by the Supreme Court, the event is likely to be treated as a once-in-a-lifetime thrill. But TVA v. Hill was not an isolated example of the high court's judicial regard for and reliance on George's scholarship. The year after it decided TVA v. Hill, the Court ruled that federal laws that restricted the sale of bald or golden eagles or parts of those birds did not amount to a taking of property without

77. Pub. L. No. 93-205, 87 Stat. 884 (1973) (codified as amended at 16 U.S.C. §§ 1531-1544).

78. George Cameron Coggins, Conserving Wildlife Resources: An Overview of the Endangered Species Act of 1973, 51 N.D. L. REV. 315, 315 (1975) [hereinafter Coggins, Conserving Wildlife Resources].

79. 437 U.S. 153 (1978).

80. 16 U.S.C. $§ 1536(a)(2)$ (2018) (requiring every federal agency to "insure that any action authorized, funded, or carried out by such agency ... is not likely to jeopardize the continued existence of any endangered species or threatened species or result in the destruction or adverse modification of habitat of such species which is determined ... to be critical").

81. Hill, 437 U.S. at $184-95$.

82. Id. at 177 (alteration in original) (quoting Coggins, Conserving Wildlife Resources, supra note 78, at 321). The Court also cited the Coggins article in a footnote to support the proposition that wildlife protection laws that predated the ESA had limited impact. See id. at 174 n.20. 
just compensation in violation of the Fifth Amendment's Takings Clause. ${ }^{83}$ Justice William Brennan's opinion for the Court twice cited a 1977 article written by George and one of his research assistants ${ }^{84}$ that analyzed the Migratory Bird Treaty Act of $1918 .^{85}$ At that point, George's assistance to the Court was half done. In 1987, the Court cited the first edition of the Coggins and Wilkinson casebook to substantiate the absence of "primary jurisdiction" by any federal agency over the outer continental shelf. ${ }^{86}$ Finally, in an effort to assure symmetry, Justice John Paul Stevens cited George's 1975 article on the ESA again in a dissenting opinion from a 2007 decision. ${ }^{87}$ In that case, the Court's majority arguably neutered TVA v. Hill by interpreting the Clean Water Act to create an exemption from the ESA for Environmental Protection Agency decisions on whether to delegate permitting authority to a state. ${ }^{88}$ The majority, in diluting the ESA's mandates, did not cite George's work.

\section{The Lower Federal Courts Discover George's Insights}

The lower federal courts also found George's scholarship to be indispensable. In 1992, a federal district court in Washington State issued a sweeping injunction halting the Forest Service from authorizing timber harvesting in old growth forests in the Pacific Northwest to remedy violations of the ESA ${ }^{89}$ It cited a 1981 article by George ${ }^{90}$ to substantiate "the Forest Service's habit of maximizing timber production at the cost of the other statutory values" that the National Forest Management Act (NFMA) was enacted to promote. ${ }^{91}$ Other lower court opinions cited

\footnotetext{
83. Andrus v. Allard, 444 U.S. 51 (1979).

84. George Cameron Coggins \& Sebastian T. Patti, The Resurrection and Expansion of the Migratory Bird Treaty Act, 50 COLO. L. REV. 165 (1979).

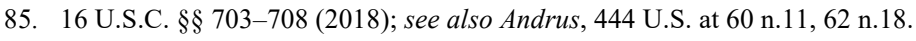

86. Amoco Prod. Co. v. Village of Gambell, 480 U.S. 531, 552 (1987).

87. Nat'l Ass'n of Home Builders v. Defs. of Wildlife, 551 U.S. 644, 675 (2007) (Stevens, J., dissenting).

88. Id. at 678; see also J.B. Ruhl, The Endangered Species Act's Fall from Grace in the Supreme Court, 36 HaRV. EnVTL. L. Rev. 487, 505 (2012) ("In National Association of Home Builders v. Defenders of Wildlife, a 5-4 majority of the Court finished the about-face from Hill by deciding that the FWS and [National Marine Fisheries Service] had reasonably interpreted the section 7 consultation procedure to apply only to 'discretionary action' federal agencies take under their respective authorizing statutes." (footnote omitted)).

89. Seattle Audubon Soc'y v. Moseley, 798 F. Supp. 1484 (W.D. Wash. 1992), aff'd sub nom. Seattle Audubon Soc'y v. Espy, 998 F.2d 699 (9th Cir. 1993).

90. George C. Coggins \& Michael E. Ward, The Law of Wildlife Management on the Federal Public Lands, 60 OR. L. ReV. 59 (1981).

91. Seattle Audubon Soc' $y, 798$ F. Supp. at 1490. A federal district court in Texas later cited the same article for the same point. Sierra Club v. Espy, 822 F. Supp. 356, 366 n.17 (E.D. Tex. 1993), rev'd, 18 F.3d 1202 (5th Cir. 1994).
} 
George's scholarship on the Wilderness Act. ${ }^{92}$ The Coggins and Glicksman treatise has been cited on a wide range of issues, including a Federal Tort Claims Act suit against the BLM $;{ }^{93}$ the scope of mineral rights reserved by the United States in patents issued under the StockRaising Homestead Act; ${ }^{94}$ the implementation of the NFMA's species viability and diversity requirements $;{ }^{95}$ the validity of a Forest Service travel management plan; ${ }^{96}$ a breach of contract claim against the Forest Service in connection with a timber sale contract; ${ }^{97}$ the imposition of criminal penalties for violating the Federal Onshore Oil and Gas Leasing Reform Act; ${ }^{98}$ the constitutional validity of Federal Land Policy and Management Act's veto provisions concerning public land withdrawals; ${ }^{99}$ the use of motorcycles in roadless areas of the national forests; ${ }^{100}$ the use of snowmobiles in the national forests; ${ }^{101}$ land surveying in connection with the issuance of land patents; ${ }^{102}$ and an alleged taking resulting from flood damage that occurred during Hurricane Katrina. ${ }^{103}$

\section{The Influential Rangeland Management Series}

One of George's most ambitious projects was a series of articles addressing the laws governing multiple use management of the public lands by the BLM, particularly as those laws apply to grazing activity. George, by himself and with various research assistants, produced a fivepart series on The Law of Public Rangeland Management, all of which were published between 1982 and 1984 in his publication venue of choice, Environmental Law, a journal published at Lewis and Clark Law School. The articles stemmed from George's work as a member of the National

92. Wyoming v. U.S. Dep't of Agric., 570 F. Supp. 2d 1309, 1346 (D. Wyo. 2008), rev'd, 61 F.3d 1209 (10th Cir. 2011) (citing Robert L. Glicksman \& George Cameron Coggins, Wilderness in Context, 76 DEN. U. L. REv. 383, 387 (1999)); Wyoming v. U.S. Dep't of Agric., 277 F. Supp. 2d 1197, 1232 (D. Wyo. 2003), vacated as moot, 414 F.3d 1207 (10th Cir. 2005) (same).

93. Maher v. United States, 56 F.3d 1039, 1047 n.4 (9th Cir. 1995) (Norris, J., dissenting).

94. Hughes v. MWCA, Inc., 12 F. App'x 875, 878 (10th Cir. 2001).

95. Citizens for Better Forestry v. U.S. Dep’t of Agric., 481 F. Supp. 2d 1059, 1091 (N.D. Cal. 2007).

96. Idaho Conservation League v. Guzman, 766 F. Supp. 2d 1056, 1061 (D. Idaho 2011).

97. Pew Forest Prod. v. United States, 105 Fed. Cl. 59, 65 (2012).

98. United States v. DeChristopher, 695 F.3d 1082, 1103 n.3 (10th Cir. 2012) (Briscoe, J., concurring in part and dissenting in part) (referring to the book as "a leading treatise").

99. Yount v. Salazar, 933 F. Supp. 2d 1215, 1236 (D. Ariz. 2013), aff'd sub nom. Nat'l Mining Ass'n v. Zinke, 877 F.3d 845 (9th Cir. 2017)

100. Biodiversity Conservation All. v. U.S. Forest Serv., 765 F.3d 1264, 1269 (10th Cir. 2014).

101. WildEarth Guardians v. Mont. Snowmobile Ass'n, 790 F.3d 920, 929 (9th Cir. 2015).

102. United States v. Estate of Laverne St. Clair, 819 F.3d 1254, 1256 (10th Cir. 2016).

103. St. Bernard Par. Gov't v. United States, 887 F.3d 1354, 1360 n.3 (Fed. Cir. 2018), cert. denied, 139 S. Ct. 796 (2019). 
Academy of Sciences Rangeland Management Commission from 1980 to 1981. ${ }^{104}$ George sketched out the trajectory of all five articles in the first one.

The articles comprised what one observer called "an exhaustive treatment of public rangeland issues and law." 105 The first article outlined the general legal framework in which range managers operate. As that article explained, the second article would "demonstrate that collapse of rangeland ecosystems in the late nineteenth century was due largely to a lack of conservation law and that administration under the Taylor Grazing Act of 1934 was ineffective in repairing the damage done"; the third would "examine areas of law which, although peripheral to rangeland management, influence its content and direction"; the fourth would describe how the BLM had "fail[ed] to institute multiple-use, sustained yield management" as required by law and "fail[ed] to improve rangeland condition"; and the final piece would offer "a comprehensive program for management improvement." 106

As might have been expected, George's prescriptions for reform in the final article were not half-way measures. He attributed what he regarded as decades of mismanagement of the public rangelands to the fact that "the regulated livestock industry has controlled the regulator agency. Consequently, private profit always has taken precedence over ecologic integrity of the range resources. Range productivity suffered because the rule of law was never rigorously applied to overcome the lingering

104. George served on the Commission again from 1989 to 1991, even though he later remarked that "I am as anti-committee as anybody you can find. .. . [T] hey keep putting me on "em and I keep not going to "em." Interview with Professor Coggins, supra note 2, at 18. He did go to the National Academy of Sciences meetings. Id. at 16. The five articles were George Cameron Coggins, Parthenia Blessing Evans \& Margaret Lindberg-Johnson, The Law of Public Rangeland Management I: The Extent and Distribution of Federal Power, 12 ENVTL. L. 535 (1982); George Cameron Coggins \& Margaret Lindberg-Johnson, The Law of Public Rangeland Management II: The Commons and the Taylor Act, 13 ENVTL. L. 1 (1982); George Cameron Coggins, The Law of Public Rangeland Management III: A Survey of Creeping Regulation at the Periphery, 1934-1982, 13 ENVTL. L. 295 (1983) [hereinafter Coggins, Rangeland III]; George Cameron Coggins, The Law of Public Rangeland Management IV: FLPMA, PRIA, and the Multiple Use Mandate, 14 ENVTL. L. 1 (1983) [hereinafter Coggins, Rangeland $\mathrm{IV}$ ]; George Cameron Coggins, The Law of Public Rangeland Management $V$ : Prescriptions for Reform, 14 ENVTL. L. 497 (1984) [hereinafter Coggins, Rangeland V].

105. D. Bernard Zaleha, The Rise and Fall of BLM's "Cooperative Management Agreements": A Livestock Management Tool Succumbs to Judicial Scrutiny, 17 ENVTL. L. 125, 129 n.15 (1986); see also Richard H. Braun, Emerging Limits on Federal Land Management Discretion: Livestock, Riparian Ecosystems, and Clean Water Law, 17 ENVTL. L. 43, 53 n.27 (1986) (stating that the five articles "provid[e] a comprehensive treatment of range law"); Robert H. Nelson, How to Reform Grazing Policy: Creating Forage Rights on Federal Rangelands, 8 FORDHAM ENVTL. L.J. 645, 665 n.128 (1997) (praising the Public Rangeland articles for their "comprehensive treatment of FLPMA and other aspects of the legal regime for the management of BLM lands").

106. Coggins, Evans \& Lindberg-Johnson, supra note 104, at 538. 
commons tragedy." 107 George therefore asserted that "[r]eforms aimed merely at correcting the abuses, mismanagement, and unlawful actions identified in prior articles would not be adequate. Instead, complete and radical reform of management philosophy and practice should be a national priority." 108

As might also have been expected, George also downplayed the significance of his work, predicting that his "reform prescriptions probably will not be adopted, at least in the near future. Even if they are adopted, they probably will not cure all management ills. I suspect that if these articles have any importance, it lies less in their analyses or conclusions than in their novelty." 109 But several courts cited one or more of the Public Rangeland series, ${ }^{110}$ and in 1995, the Clinton Administration's Interior Department adopted regulations that reformed the rules and procedures governing the BLM's management of the range, ${ }^{111}$ relevant parts of which were upheld by the Supreme Court. ${ }^{112}$

\section{Wildlife, Watershed, Devolution, and Discretion}

During his sustained period of scholarly productivity, George also devoted considerable attention to wildlife law, writing about the Migratory Bird Treaty Act, ${ }^{113}$ wildlife law and Native Americans, ${ }^{114}$ and wildlife protection in the national parks. ${ }^{115} \mathrm{He}$ also analyzed aspects of multiple use management other than rangeland management, urging the "unearthing" of judicially enforceable standards to constrain the discretion

107. Coggins, Rangeland V, supra note 104, at 546.

108. Id. at 499 .

109. Id. at 546.

110. See Buckingham v. Sec'y of U.S. Dep't of Agric., 603 F.3d 1073, 1077 (9th Cir. 2010) (citing Coggins, Rangeland IV, supra note 104, at 23-24); Public Lands Council v. Babbitt, 167 F.3d 1287, 1295 (10th Cir. 1999), aff'd, 529 U.S. 728 (2000) (citing Coggins \& Lindberg-Johnson, supra note 104, at 69); id. at 1300 (citing Coggins, Rangeland IV, supra note 104, at 24). For another decision citing George's work on multiple use management, see New Mexico ex rel. Richardson v. Bureau of Land Mgmt., 459 F. Supp. 2d 1102, 1121 n.14 (D.N.M. 2006), aff'd in part, vacated in part, and rev'd in part, 565 F.3d 683 (10th Cir. 2009) (citing George Cameron Coggins \& Parthenia Blessing Evans, Multiple Use, Sustained Yield Planning on the Public Lands, 53 U. CoLO. L. REV. 411, 464 (1982)).

111. Department Hearings and Appeals Procedures; Cooperative Relations; Grazing Administration-Exclusive of Alaska, 60 Fed. Reg. 9894 (Feb. 22, 1995).

112. See Pub. Lands Council v. Babbitt, 529 U.S. 728 (2000).

113. Coggins \& Patti, supra note 84.

114. George Cameron Coggins \& William Modrcin, Native American Indians and Federal Wildlife Law, 31 STAN. L. REV. 375 (1979).

115. George Cameron Coggins, Protecting the Wildlife Resources of National Parks from External Threats, 22 LAND \& WATER L. REV. 1 (1987). George also urged preservation of plant diversity. See George Cameron Coggins \& Anne Fleishel Harris, The Greening of American Law?: The Recent Evolution of Federal Law for Preserving Floral Diversity, 27 NAT. RESOURCES J. 247 (1987). 
of the Forest Service and the BLM. ${ }^{116}$ George offered what has to be the definitive criticism of James Watt's highly destructive tenure as Interior Secretary during the Reagan Administration. ${ }^{117} \mathrm{He}$ also launched a sustained diatribe ${ }^{118}$ against efforts to disguise abdication of proper federal management of public lands and resources by couching it in the language of "devolution" popularized by movements such as the Sagebrush Rebellion. ${ }^{119}$ Finally, in what he described as yet another experiment, George urged recognition of and increased emphasis on watershed as a separate public natural resource in the multiple use, sustained yield context. ${ }^{120}$ Scholars have since accorded the watershed resource exactly that treatment, ${ }^{121}$ as have some courts. ${ }^{122}$

\section{The Impact of George Coggins's Scholarship, Past and Future}

In a final effort to push for what he regarded as essential changes in public land law, George self-published in 2011 a book titled Restoration: An Immodest Blueprint for Federal Public Land Law and Resources Law Reform in the 21st Century. The book's "immodest" goal was "restoration of America's natural heritage." 123 Recently, public lands scholars and

116. See George Cameron Coggins, Of Succotash Syndromes and Vacuous Platitudes: The Meaning of "Multiple Use, Sustained Yield" for Public Land Management, 53 U. Colo. L. REV. 229 (1982).

117. George Cameron Coggins \& Doris K. Nagel, "Nothing Beside Remains": The Legal Legacy of James G. Watt's Tenure as Secretary of the Interior on Federal Land Law and Policy, 17 B.C. ENVTL. AFF. L. REV. 473 (1990).

118. George remarked in an interview after his retirement that "actually a lot of my articles tend to be strident in tone, but I've gotten away with it pretty well." Interview with Professor Coggins, supra note 2, at 16 .

119. George C. Coggins, Regulating Federal Natural Resources: A Summary Case Against Devolved Collaboration, 25 ECOLOGY L.Q. 602 (1999); George Cameron Coggins, "Devolution" in Federal Land and Law: Abdication by Any Other Name..., 3 HASTINGS W.-N.W. J. ENVTL. L. \& POL'Y 211 (1996); George Cameron Coggins, "Devolution" in Federal Land Law: Abdication by Any Other Name. ., 14 HASTINGS W.-N.W. J. ENVTL. L. \& POL'Y 485 (2008).

120. George Cameron Coggins, Watershed as a Public Natural Resource on the Federal Lands, 11 VA. ENVTL. L.J. 1, 3 (1991). FLPMA lists watershed as a multiple use. 43 U.S.C. § 1702(c) (2018).

121. See, e.g., Mary Tharin, Restoring Our Nation's Waters Through Public Land Law, 39 ECOLOGY L.Q. 571, 582-83 (2012); W. Wallace Covington \& Diane Vosick, Restoring the Sustainability of Frequent-Fire Forests of the Rocky Mountain West, 48 ARIZ. ST. L.J. 11, 15 (2016); see also Justin K. Holcombe, Protecting Ecosystems and Natural Resources by Revising Conceptions of Ownership, Rights, and Valuation, 26 J. LAND RESOURCES \& ENVTL. L. 83, 86 (2005) (referring to "the renewed attention to protecting watershed resources").

122. See, e.g., Sierra Club v. Glickman, 974 F. Supp. 905, 926-29 (E.D. Tex. 1997), aff'd sub nom. Sierra Club v. Peterson, 185 F.3d 349 (5th Cir. 1999), vacated and remanded, 228 F.3d 559 (5th Cir. 2000) (finding no reviewable final agency action).

123. George Cameron Coggins, Restoration: An Immodest Blueprint for Federal Public Land LAW AND Resources Law REForm In the 21st CEnTURY i (2011). George dedicated the book to his middle child, Rebecca. Id. at ii. The book's dedication page informed readers that 
advocates have considered the possibility of convening a second Public Land Law Review Commission. ${ }^{124}$ It would be modeled after the Commission that produced the 1970 report, One Third of a Nation's Land, ${ }^{125}$ on the occasion of the fiftieth anniversary of that report's publication. ${ }^{126}$ Professor Robert Keiter of the University of Utah S.J. Quinney College of Law and Matthew McKinney, the Director of the Center for Natural Resources \& Environmental Policy at the University of Montana, have concluded that "in today's polarized political climate, it would be difficult at this moment to undertake a similar comprehensive review with an eye toward meaningful reform." 127 Nevertheless, they acknowledge the need "to critically examine the successes and shortcomings in current management approaches, and to develop thoughtful recommendations to reshape public land law, policy, and governance over the next several decades ... and to envision what a new paradigm for the nation's irreplaceable public lands might look like." ${ }^{28}$ I suggest that, if any such effort is taken, the ideas set forth in Restoration would be one good place to start the debate.

The impact of George's scholarship has been (and continues to be) enormous. As of the end of 2019, George's work had been cited more than 1000 times in Westlaw's Law Review \& Journals database in works spanning forty years. Fittingly, George's article on protection of migratory birds was cited in 2019 in the Michigan Law Review, for which he toiled as an upper-class law student. ${ }^{129}$ Just as fittingly, the citation appeared in a Note written by a Michigan law student, who perhaps was inspired by and has received the training to follow in George's footsteps. The same article was cited in Environmental Law, George's most frequent venue for law review publications, in 2019. ${ }^{130}$ Among the remarks circulated among environmental law professors after George's passing were many encomiums to his valuable contributions to public land law.

\footnotetext{
"she prefers 'Becca,' but, as her father, I can call her any damn thing I please." Id. George once requested that my kids call him "Sir George." They did.

124. Adam M. Sowards, It's Time to Revisit an Old Way to Resolve Public Land Fights: Commissions Offer a Way to Navigate Thorny Policy Questions and Find Consensus, HigHCOUNTRY NEWS (Feb. 26, 2019), https://www.hen.org/issues/51.5/reckoning-with-history-its-time-to-revisit-an -old-way-to-resolve-public-land-disputes [https://perma.cc/57D9-HPBM].

125. PUB. LAND LAW REVIEW COMM'N, supra note 50.

126. Sowards, supra note 124.

127. Keiter \& McKinney, supra note 52, at 69.

128. Id. at 69-70. Here is yet another paradigm for George (and his work) to subvert.

129. Patrick G. Maroun, More Than Birds: Developing a New Environmental Jurisprudence Through the Migratory Bird Treaty Act, 117 MicH. L. REV. 789, 793 n.19 (2019).

130. Jessica Scott \& Andrea Folds, From Friend to Foe: The Complex and Evolving Relationship of the Federal Government and the Migratory Birds It Is Bound to Protect, 49 EnVTL. L. 187, 191 nn. 20 \& 24 (2019).
} 
One person wrote that "we shall rely on his contributions to law. They live on." Others called him "a giant in his field," "a true legend," and "a true pioneer, in an era where it was needed." The rich body of scholarship that George left behind is sure to engender thoughtful debate over the future of the federal lands and resources for a good long while.

\section{Conclusion}

George Coggins arrived in Lawrence in 1970 unsure whether he would stay longer than a year. He stayed nearly fifty years, forty of which he spent as a member of the KU Law faculty. During that time, he provided a model of what being a serious scholar is all about (and for some, like me, he served as a mentor, a term he surely would have hated being applied to him). George once described his scholarship as having "little to do with Kansas law or Kansas politics or Kansas everything, because my subject is by its nature national." 131 While true, that characterization does not detract from the impact his work had on KU and its students.

George was perhaps the most prominent scholar on the KU Law faculty during his most productive period. His stature surely helped shine a positive light on the scholarship of the KU faculty more generally. It also surely made KU Law a more attractive place to study and work for those interested in environmental and natural resources law. ${ }^{132}$ George also made his mark in the classroom. He had a reputation for being somewhat intimidating, but that was not the reality, and those who thought it soon discovered otherwise. ${ }^{133}$ I know that students who took my courses

131. George and I did write a lengthy report on how to manage groundwater pollution in Kansas. George Cameron Coggins \& Robert L. Glicksman, a Proposed Strategy to Prevent GROUNDWATER CONTAMINATION IN KANSAS (1986) (on file with author). With a change in the political affiliation of Kansas's governor, the project, which we submitted to (and wrote at the behest of) the Kansas Department of Health and the Environment, was shelved. We followed up the report by publishing two law review articles that elaborated on the report's findings, analysis, and recommendations. See Robert L. Glicksman \& George Cameron Coggins, Groundwater Pollution I: The Problem and the Law, 35 U. KAN. L. Rev. 75 (1986); George Cameron Coggins \& Robert L. Glicksman, Groundwater Pollution II: An Immodest Proposal for a Strategy to Prevent Groundwater Pollution, 35 U. KAN. L. REV. 241 (1987). George was apparently fond of "immodest proposals." He accurately predicted that the strategy reflected in the second article would never see the light of day, if for no other reason than that it centered on a groundwater severance tax in a state heavily dependent on irrigated agriculture. See id. at 262-63. George was not deterred. He thought it was a good idea. Perhaps that experience convinced him, however, that his time would henceforth be better spent on national rather than state or local issues.

132. I, for one, salivated at the prospect of being able to work as a fledgling environmental law professor with George as my colleague. He went out of his way to turn that hope into reality. His generosity in sharing his ideas, and credit for work that he initiated, was remarkable.

133. Professor Mike Davis, who was Dean of KU Law for much of the 1980s, remarked that "all of his colleagues on the faculty, all of the staff at the law school and most of the students figured out the inner teddy bear that is the real George long, long ago." Paget, supra note 61, at 13. 
always smiled when they recounted to me their experiences in George's classes. Jim May reports that although George was fond of telling students that he was not there to entertain them, he effortlessly did just that.

it.

George Coggins was, indeed, one of a kind. That's the way he liked 